\title{
Chemical interaction between white onion, as natural antioxidant, on shrimp stored under freezing
}

\author{
Giselda Macena LIRA ${ }^{1 *}$ (D), Ana Maria Queijeiro LOPEZ², Gabriela Marques de Farias NANES'1, \\ Fernanda Geny Calheiros SILVA ${ }^{1}$
}

\begin{abstract}
The impact of white onion as a natural antioxidant on the lipid profile of "Vila Franca" shrimp (Litopenaeus schmitti Burkenroad, 1938), during storage under freezing, was evaluated by changes in the composition of fatty acids, carotenoids, centesimal composition and phenols. The lipid content in the shrimp samples in natura and with white onion was dimmed after 45 days of storage under freezing. At zero time and during storage, lower levels of fatty acids were detected in the shrimp with addition of white onion. There was a reduction in the total carotenoid content of fresh and white onion shrimp samples after 45 days of storage, corresponding to $30 \%$ and $43 \%$, respectively. After 90 days of storage, was detected a loss of $28 \%$, in the samples with addition of white onion, in relation to 45 days. In spite of the linear increase in phenol content during storage, no positive correlation was observed between the concentrations of phenols and the antioxidant activity exerted by white onion, in relation to the profile of fatty acids and carotenoids of the food.
\end{abstract}

Keywords: fish; vegetables; fatty acids; centesimal composition; phenols.

Practical Application: As the use of natural antioxidants has been encouraged due to health benefits, this study has an importance in obtaining information for the conservation of shrimp, a food susceptible to undergo lipid oxidation during storage under freezing. The white onion, a vegetable commonly used in cooking preparations, had a negative antioxidant impact on the fatty acid profile and the carotenoid content of the crustacean.

\section{Introduction}

Shrimp production has increased significantly in recent years and can be classified as the product of the greatest economic impact in the world, mainly due to the high utilization in the gastronomic sector (Becerra et al., 2014) and considerable nutritional importance, being a food source of the high-value proteins, minerals (Pedrosa \& Cozzolino, 2001) and polyunsaturated fatty acids of the omega 3 series, especially Eicosapentaenoic (EPA) and Docosahexaenoic (DHA) (Furuya et al., 2006; Simon et al., 2012; Lira et al., 2014), which present several beneficial effects in the organism (Costa et al., 2009; Perini et al., 2010; Ruxton, 2011; Ruxton et al., 2005). Shrimp is also a source of carotenoids (Lira et al., 2017), with astaxanthin being the major source (Armenta \& Guerrero-Legarreta, 2009).

In natura and frozen shrimp are the main presentations under which this crustacean is marketed (Becerra et al., 2014). During the storage of the shrimp, the polyunsaturated fatty acids can undergo lipid oxidation reactions, having their profile modified. These reactions directly affect the quality of the food, by reducing the shelf life due to the rancid, odor and strong flavor characteristic of the phenomenon, in addition to being able to develop substances that are harmful to the health of the consumer (Pokorny et al., 2008).

One of the strategies to inhibit the occurrence of lipid oxidation is from the use of antioxidants, for its ability to hijack or prevent the formation of free radicals (Kulawik et al., 2013). The use of natural antioxidants can generate health benefits related to the immune system, heart disease and cancer prevention (Hathwar et al., 2012; Haugaard et al., 2014). Vegetables represent one of the natural sources of antioxidants (Abreu et al., 2011; Selani et al., 2011). The protective effect exerted by these foods has been attributed to the presence of phenolic compounds, $\beta$-carotene, vitamin C and vitamin E (Melo et al., 2006).

White onion (Allium cepa L.) is a vegetable widely used in culinary preparations. However, there is no information in the scientific literature about its effect as a natural antioxidant. The "Vila Franca" shrimp (Litopenaeus schmitti Burkenroad, 1938), also called "Caboclo" and "White" shrimp in the Northeast Brazil, is a prominent crustacean in such region due to its size (about $18 \mathrm{~cm}$ in length) and flavor. It is exploited artisanal and a with relevant interest. Considering the socioeconomic importance of shrimp in the Northeast State of Alagoas (Brazil), where the water reaches high salinity ( $35.5 \mathrm{psu}$ ) and medium temperature $27.8^{\circ} \mathrm{C}$ (Araújo, 2006), together with the nutritional value of this crustacean, the objective of this pioneering work was to evaluate the impact of white onion (Allium cepa L.) on the prevention of lipid oxidation in "Vila franca" shrimp (L. schmitti) during storage under freezing. 


\section{Methodology}

\subsection{Samples preparation}

White onions (Allium cepa L.) were purchased at a supermarket located in Maceió-AL and then transported to the laboratory, where the epidermis, stalk and roots were removed.

Regarding the shrimps, two batches of $4.0 \mathrm{Kg}$ of the "Vila Franca' shrimp (L. schmitti), from the coastline (geographic coordinates 8'8'12"S and 10²9'12"S) of Maceió-Alagoas/Brazil, was acquired in september 2016, soon after collected. The samples were placed in plastic bags, kept in cooler box with ice and immediately transported to the laboratory. These batches were split into two groups of $2.0 \mathrm{Kg}$.

Group "I" was formed without the addition of white onion and group "II" was formed with the addition of $5 \%$ of this vegetable. This percentage was established because it is usually used in cooking preparations. In both groups, the residue of the head and intestines, shells from the exoskeleton carapace, plus tail and legs of the shrimps were removed. Only the fillets were used. As the mass of fillets for the analyzes was $30 \mathrm{~g}$ (without addition and with addition of $5 \%$ white onion), it was estimated that the amount of acquired sample per group (1 Kg) was sufficient. Then, the mass of appropriate aliquots of fillets ( $30 \mathrm{~g}$ ) of the groups I and II samples (respectively without addition and with addition of 5\% white onion) randomly collected were measured and identified for analysis. The remaining samples (without addition and with addition of $5 \%$ white onion) were packed in aseptic plastic bags, identified and stored in plastic containers in the freezer at $-17^{\circ} \mathrm{C}\left( \pm 1^{\circ} \mathrm{C}\right)$, until the moment of the analysis ( 0,45 and 90 days under freezing). The "time zero" samples were processed at the same day, whilst the others were stored under freezing until the interval settled for the analysis (45 or 90 days).

\subsection{Chemical analysis}

The following determinations were made, in triplicate:

\section{Centesimal composition}

The moisture, protein and ash contents were determined using Association of Official Analytical Chemists (2000) methodologies. Total lipid was extracted by Folch et al. (1957) and the lipid content was gravimetrically determined. The caloric value was calculated from the caloric coefficients corresponding to the proteins and lipids (Livesey, 1990).

\section{Extraction of carotenoids}

The carotenoid pigments were extracted from the fillets samples (30 g) through homogenization with $92.8^{\circ} \mathrm{GL}$ ethanol $(100 \mathrm{~mL})$ in a blender during $5 \mathrm{~min}$. The commercial ethanol $\left(92.8^{\circ} \mathrm{GL}\right)$ was used since it enables a better extraction with less cost and it is a less toxic solvent (Santos et al., 2012). Each crude extract was centrifuged at $10,000 \mathrm{rpm}$ at $4{ }^{\circ} \mathrm{C}$ for $20 \mathrm{~min}$, and the supernatant (liquid phase) was stored in amber bottles, while the precipitate (16 g) was re-homogenized for $5 \mathrm{~min}$ with commercial ethanol until the complete removal of pigments $(56 \mathrm{~mL})$. The second supernatant was added to the first and the mixture was filtered (filter paper) before the final collection on a second amber vial. To avoid possible oxidation due to contact with oxygen from the air, nitrogen gas was sprayed into the vial before being closed. Then it was stored in a freezer at $-17^{\circ} \mathrm{C}\left( \pm 1{ }^{\circ} \mathrm{C}\right)$ until the next day when the total carotenoids were determined.

\section{Determination of carotenoids content}

The absorbance of $1 \mathrm{~mL}$ of each ethanolic extract was measured at $470 \mathrm{~nm}$ using a spectrophotometer. The "blank" reference corresponded to $1 \mathrm{~mL}$ of ethanol (Schiedt \& Liaaen-Jensen, 1995). The concentration of carotenes in the extract was determined using the following equation (Equation 1), wherein " $\mathrm{A}$ " is the absorbance at $470 \mathrm{~nm}$, "vol" is the volume $(\mathrm{mL})$ used in the extraction of carotenoids and "A $1 \%$ " is the absorption coefficient for $1 \%$ of the mixture of unknown carotenes at 2500:

Total Carotenoids $(\mathrm{mg})=\frac{A \times \mathrm{vol} \times 1000}{A_{l \mathrm{~cm}}^{1 \%} \times 100}$

\section{Fatty acid profile}

Aliquots of lipid extracts obtained according to Folch et al. (1957) were converted to methyl esters (Hartman \& Lago, 1973) and injected into a gas phase (GC) chromatograph (GC Gas Chromatograph 2010 plus Shimadzu/GC solution software, SP-2560 fused silica chromatography non-bonded poly (biscianopropyl siloxane) Column and with a length, internal diameter and $\mathrm{df}$ of $(100 \mathrm{~m} \times 0.25 \mathrm{~mm} ; 0.20 \mu \mathrm{m})$; temperature programming: isothermal at $140{ }^{\circ} \mathrm{C}$ for $5 \mathrm{~min}$ and then heating at $4^{\circ} \mathrm{C} / \mathrm{min}$ to $240{ }^{\circ} \mathrm{C}$ (remaining at this for $20 \mathrm{~min}$ ); Vaporizer temperature: $250{ }^{\circ} \mathrm{C}$; Detector temperature: $260{ }^{\circ} \mathrm{C}$; Carrier gas: Helium (1 mL / min.); Sample split ratio: 1/50; Standard fatty acid methyl esters were used, comparing the retention time of the methyl esters of the samples and the standards. The quantification of the fatty acids was done by normalization of area, expressing the result in $\mathrm{mg} / 100 \mathrm{~g}$.

\section{Determination of total phenolic compounds}

The white onion samples were cut into thin layers, approximately $1 \mathrm{~cm}$, and dehydrated at $40{ }^{\circ} \mathrm{C}$ to concentrate the solids and facilitate the extraction process of the phenols, maintaining the ratio of dry mass / solvent. The samples were macerated, according to Elfalleh et al. (2012) and homogenized at $80 \%$ methanol, at a ratio of $1: 10(\mathrm{~m} ; V)$. The total phenolic contents were measured by spectrophotometry, according to Singleton, Orthofer; Lamuela-Raventos (1999), modified by Meda et al. (2005). The obtained dry extract was diluted in $80 \%$ methanol, obtaining a concentration of $2000 \mu \mathrm{g} / \mathrm{mL}$, homogenized with $250 \mu \mathrm{L}$ of the Folin-Ciocalteau reagent, $2 \mathrm{~mL}$ of $7.5 \%$ calcium carbonate and $6 \mathrm{~mL}$ of distilled water and allowed to stand, at room temperature for 2 hours. The absorbance was measured at $750 \mathrm{~nm}$ and the results were expressed as gallic acid equivalent (mg gallic acid / $100 \mathrm{~g}$ sample extract). 


\section{Statistical analyzes}

The data of fatty acids were submitted to analysis of variance (ANOVA) by the statistical program SPSS ${ }^{\circledR}$ Statistics (Pereira, 2003), and the averages of the treatments compared by the Tukey test, at $5 \%$ of significance.

\section{Results and discussion}

\subsection{Centesimal composition}

The results of the analyzes of centesimal composition of "Vila Franca" shrimp in natura and with addition of white onion are presented in Table 1.

It was verified that the moisture, ash and protein contents, in fresh shrimp and with white onion, at different storage times under freezing did not present a statistically significant difference $(p>0.05)$, indicating that, the consumer can the protein content of this food until the 90 days of storage. There was also no significant difference ( $\mathrm{p}>0.05$ ) between the in natura and white onion samples.

The in natura samples presented lower protein levels than those found in freshwater "Pitu" shrimp (Macrobrachium acanthurus - Wiegman, 1836), which corresponded to $23.6 \%$ (Simon et al., 2012). However, Pedrosa \& Cozzolino (2001) found $10.62 \%$ of the protein in fresh pink shrimp, a value lower than that detected in this study.

The "Vila Franca" shrimp in natura presented low lipid content $(1.58 \mathrm{~g} / 100 \mathrm{~g})$, which can be considered as lean food (Ackman, 1989). Similar results were found with freshwater "Pitu" shrimp (M. acanthurus) in natura, corresponding to $1.6 \mathrm{~g} / 100 \mathrm{~g}$ (Simon et al., 2012).

The lipid content of the in natura and white onion samples showed a significant reduction $(\mathrm{p}<0.05)$ after 45 days of storage under freezing, evidencing that the white onion was not able to protect the food against lipid oxidation. Both groups presented maintenance of their lipid contents until 90 days. There were no significant differences ( $\mathrm{p}>0.05)$ between the percentages of in natura shrimp lipids compared to the crustacean with white onion addition, during the various storage times under freezing.

\section{Fatty acid profile}

The results of the fatty acid profile identified in the samples of the "Vila Franca" shrimp in the in natura form and with the addition of white onion stored in the different freezing times are presented in Table 2.

The saturated fatty acids that were most expressive, in all analyzed periods, in the samples in natura and with the addition of white onion, were the Palmitic and Stearic acids. Among the monounsaturated fatty acids, it was found the Oleic and Palmitoleic and with relation polyunsaturated, the Eicosapentaenoic, Docosahexaenoic and Arachidonic. These results are in agreement to those reported by Simon et al. (2012) in "Pitu" freshwater shrimp (M. acanthurus) in natura and Lira et al. (2014) and in spiny shrimp (Xiphopenaeus kroyeri Heller,1862) in natura.

In the two groups analyzed, there was a significant increase $(\mathrm{p}<0.05)$ in the contents of these saturated, monounsaturated and polyunsaturated fatty acids after 45 days of storage, in relation to time zero, and it could be assumed that a concentration occurred, since it was observed the storage period. However, after 90 days, there was a significant $(\mathrm{p}<0.05)$ decline in the concentrations of these fatty acids, both in the in natura samples and in those with white onion addition, probably due to the development of oxidative reactions. Freezing and storage under low temperatures are important methods used for the preservation of fish (Siddaiah et al., 2001). However, food processing often involves tissue disruptions. This brings in contact intracellular compounds originally contained within different organites and/or the cytoplasm, and also extracellular molecules (Bourvellec \& Renard, 2012). It may lead to some undesirable changes such as protein denaturation and lipid oxidation (Xia et al., 2009; Leygonie et al., 2012).

Table 1. Composition centesimal (g/100g) and caloric value (Kcal) of the "Vila Franca" shrimp in natura and with addition of white onion, under three freezing time intervals.

\begin{tabular}{|c|c|c|c|c|}
\hline \multirow{2}{*}{ Analytes* } & \multirow{2}{*}{ "Vila Franca" shrimp } & \multicolumn{3}{|c|}{ Freezing time (days) } \\
\hline & & 0 & 45 & 90 \\
\hline \multirow[t]{2}{*}{ Moisture } & In natura & $79.91 \mathrm{Aa}( \pm 0.50)$ & $79.47 \mathrm{Aa}( \pm 0.62)$ & $80.19 \mathrm{Aa}( \pm 0.49)$ \\
\hline & With white onion & $80.73 \mathrm{Aa}( \pm 0.59)$ & $79.33 \mathrm{Aa}( \pm 0.63)$ & $82.17 \mathrm{Aa}( \pm 0.34)$ \\
\hline \multirow[t]{2}{*}{ Proteins } & In natura & $14.57 \mathrm{Aa}( \pm 2.48)$ & $16.83 \mathrm{Aa}( \pm 1.71)$ & $16.36 \mathrm{Aa}( \pm 2.71)$ \\
\hline & With white onion & $13.81 \mathrm{Aa}( \pm 0.15)$ & $14.70 \mathrm{Aa}( \pm 0.89)$ & $12.10 \mathrm{Aa}( \pm 3.48)$ \\
\hline \multirow[t]{2}{*}{ Ashes } & In natura & $1.48 \mathrm{Aa}( \pm 0.04)$ & $1.30 \mathrm{Aa}( \pm 0.03)$ & $1.60 \mathrm{Aa}( \pm 0.04)$ \\
\hline & With white onion & $1.46 \mathrm{Aa}( \pm 0.21)$ & $1.30 \mathrm{Aa}( \pm 0.03)$ & $1.58 \mathrm{Aa}( \pm 0.09)$ \\
\hline \multirow[t]{2}{*}{ Lipids } & In natura & $1.58 \mathrm{Aa}( \pm 0.44)$ & $0.92 \mathrm{Ba}( \pm 0.03)$ & $0.96 \mathrm{Ba}( \pm 0.05)$ \\
\hline & With white onion & $1.28 \mathrm{Aa}( \pm 0.08)$ & $0.86 \mathrm{Ba}( \pm 0.08)$ & $0.86 \mathrm{Ba}( \pm 0.22)$ \\
\hline \multirow[t]{2}{*}{ Carbohydrates } & In natura & $2.46 \mathrm{Aa}( \pm 3.03)$ & $1.48 \mathrm{Ab}( \pm 1.10)$ & $0.89 \mathrm{Aa}( \pm 2.38)$ \\
\hline & With white onion & $2.71 \mathrm{Aa}( \pm 0.31)$ & $3.81 \mathrm{Aa}( \pm 0.85)$ & $3.29 \mathrm{Aa}( \pm 3.74)$ \\
\hline \multirow[t]{2}{*}{ Calories } & In natura & $82.34 \mathrm{Aa}( \pm 3.42)$ & $81.54 \mathrm{Aa}( \pm 2.40)$ & $77.59 \mathrm{Aa}( \pm 2.24)$ \\
\hline & With white onion & $77.63 \mathrm{Aa}( \pm 1.29)$ & $81.76 \mathrm{Aa}( \pm 3.04)$ & $69.29 \mathrm{Ab}( \pm 2.41)$ \\
\hline
\end{tabular}

${ }^{\star}$ Averages and standard deviation of two samples evaluated in triplicate. Different capital letters in the same row and different lowercase letters, in the same column, indicate a significant difference at $5 \%$ probability, by Tukey's test. 
Table 2. Fatty acids (mg/100g) of the "Vila Franca" shrimp in natura and with addition of white onion, stored under freezing.

\begin{tabular}{|c|c|c|c|c|c|c|}
\hline \multirow{2}{*}{ FATTY ACIDS } & \multicolumn{2}{|c|}{ Time 0} & \multicolumn{2}{|c|}{ Time 45 days } & \multicolumn{2}{|c|}{ Time 90 days } \\
\hline & In natura* & With onion* & In natura* & With onion $^{*}$ & In natura* & With onion* \\
\hline Mystic (14: 0) & $6.24( \pm 1.85) \mathrm{aA}$ & $5.47( \pm 0.09) \mathrm{bA}$ & $9.65( \pm 0.65) \mathrm{aB}$ & $8.86( \pm 0.45) \mathrm{bB}$ & $4.47( \pm 0.49) \mathrm{aC}$ & $3.71( \pm 0.24) b C$ \\
\hline Pentadecyl (15: 0) & $8.53( \pm 2.83) \mathrm{aA}$ & $6.45( \pm 0.61) \mathrm{bA}$ & $8.79( \pm 0.51) \mathrm{aA}$ & $7.34( \pm 0.09) \mathrm{bB}$ & $5.11( \pm 0.56) \mathrm{aC}$ & $4.95( \pm 0.28) \mathrm{aC}$ \\
\hline Palmitic (16: 0) & $84.73( \pm 25.5) \mathrm{aA}$ & $74.82( \pm 5.35) \mathrm{bA}$ & $120.8( \pm 2.4) \mathrm{Ab}$ & $109.83( \pm 0.11) \mathrm{B}$ & $56.70( \pm 6.06) \mathrm{aC}$ & $54.63( \pm 3.42) \mathrm{bC}$ \\
\hline Heptadecanoic (17: 0) & $14.95( \pm 4.78) \mathrm{aA}$ & $12.07( \pm 0.82) \mathrm{bA}$ & $17.23( \pm 1.63) \mathrm{aB}$ & $14.88( \pm 1.35) \mathrm{bB}$ & $10.09( \pm 1.5) \mathrm{aC}$ & $10.35( \pm 0.23) \mathrm{bC}$ \\
\hline Stearic $(18: 0)$ & $60.69( \pm 18.1) \mathrm{aA}$ & $51.33( \pm 4.02) \mathrm{bA}$ & $95.42( \pm 5.23) \mathrm{aB}$ & $84.49( \pm 2.79) \mathrm{bB}$ & $40.05( \pm 4.23) \mathrm{aC}$ & $38.52( \pm 2.26) b C$ \\
\hline Arachidical (20: 0) & $1.43( \pm 0.45) \mathrm{aA}$ & $1.57( \pm 0.25) \mathrm{aA}$ & $3.42( \pm 0.26) \mathrm{aB}$ & $2.98( \pm 0.11) \mathrm{B}$ & $1.03( \pm 0.14) \mathrm{aC}$ & $0.88( \pm 0.08) \mathrm{aC}$ \\
\hline Palmitolytic (16: $1 \omega-7)$ & $28.56( \pm 8.12) \mathrm{aA}$ & $23.48( \pm 0.96) \mathrm{aA}$ & $49.61( \pm 0.73) \mathrm{aB}$ & $45.22( \pm 0.79) \mathrm{bB}$ & $18.23( \pm 1.98) \mathrm{aC}$ & $17.17( \pm 1.02) b C$ \\
\hline Cis-10 Heptadecanoic (17: 1) & $8.61( \pm 4.51) \mathrm{aA}$ & $6.60( \pm 0.33) \mathrm{bA}$ & $9.30( \pm 0.40) \mathrm{aB}$ & $7.78( \pm 0.08) \mathrm{bB}$ & $4.32( \pm 0.47) \mathrm{aC}$ & $4.66( \pm 0.31) \mathrm{aC}$ \\
\hline Oleic (18: $1 \omega-9)$ & $72.05( \pm 19.3) \mathrm{aA}$ & $58.50( \pm 2.66) \mathrm{bA}$ & $106.7( \pm 0.47) \mathrm{aB}$ & $97.38( \pm 2.08) b B$ & $44.65( \pm 4.94) \mathrm{aC}$ & $42.06( \pm 2.78) b C$ \\
\hline Gadoleic (20:1 $\omega-11)$ & $5.09( \pm 1.79) \mathrm{aA}$ & $4.41( \pm 0.22) \mathrm{bA}$ & $4.28( \pm 0.21) \mathrm{aA}$ & $3.76( \pm 0.12) \mathrm{bA}$ & $2.35( \pm 0.31) \mathrm{aB}$ & $2.12( \pm 0.12) \mathrm{aB}$ \\
\hline Nervonic (24:1) & $3.52( \pm 3.81) \mathrm{aA}$ & $2.27( \pm 2.80) \mathrm{bA}$ & $0.95( \pm 0.27) \mathrm{aB}$ & $1.01( \pm 0.02) \mathrm{aB}$ & $4.40( \pm 0.48) \mathrm{aA}$ & $3.96( \pm 0.25) \mathrm{bA}$ \\
\hline Linoleic (18: $2 \omega-6)$ & $13.91( \pm 4.67) \mathrm{aA}$ & $14.29( \pm 0.39) \mathrm{bA}$ & $18.22( \pm 1.10) \mathrm{aB}$ & $16.60( \pm 0.42) b B$ & $10.24( \pm 1.14) \mathrm{aC}$ & $9.12( \pm 0.54) b C$ \\
\hline Linolenic (18: $3 \omega-3)$ & $2.63( \pm 0.70) \mathrm{aA}$ & $2.22( \pm 0.07) \mathrm{bA}$ & $3.81( \pm 0.46) \mathrm{aB}$ & $3.37( \pm 0.11) \mathrm{bB}$ & $2.13( \pm 0.23) \mathrm{aC}$ & $2.22( \pm 0.13) \mathrm{aC}$ \\
\hline Eicosadienoic acid (20: $2 \omega-6)$ & $5.35( \pm 1.52) \mathrm{aA}$ & $4.72( \pm 0.24) \mathrm{bA}$ & $7.65( \pm 0.00) \mathrm{aB}$ & $6.51( \pm 0.22) \mathrm{bB}$ & $3.73( \pm 0.41) \mathrm{aC}$ & $3.37( \pm 0.19) \mathrm{aC}$ \\
\hline Arachidonic (20: $4 \omega-6)$ & $46.70( \pm 14.3) \mathrm{aA}$ & $39.74( \pm 2.34) \mathrm{bA}$ & $79.88( \pm 0.02) \mathrm{aB}$ & $72.15( \pm 3.72) b B$ & $29.56( \pm 3.16) \mathrm{aC}$ & $28.70( \pm 1.80) b C$ \\
\hline Eicosapentaenoic (EPA) (20: $5 \omega-3)$ & $68.06( \pm 22.2) \mathrm{aA}$ & $55.47( \pm 2.24) \mathrm{bA}$ & $98.64( \pm 3.05) \mathrm{aB}$ & $92.48( \pm 4.24) \mathrm{bB}$ & $42.41( \pm 4.53) \mathrm{aC}$ & $41.13( \pm 2.6) \mathrm{bC}$ \\
\hline Docosapentaenoic (DPA) (22: $5 \omega-3)$ & $13.06( \pm 3.06)$ aA & $7.60( \pm 0.38) \mathrm{bA}$ & $12.59( \pm 0.11) \mathrm{aB}$ & $10.77( \pm 0.63) \mathrm{bB}$ & $6.21( \pm 0.65) \mathrm{aC}$ & $5.81( \pm 0.38) b C$ \\
\hline Docosahexaenoic (DHA) (22: $6 \omega-3)$ & $51.08( \pm 15.9) \mathrm{aA}$ & $41.49( \pm 1.79) \mathrm{aA}$ & $82.81( \pm 3.16) \mathrm{aB}$ & $74.75( \pm 3.55) \mathrm{bB}$ & $32.10( \pm 3.5) \mathrm{aC}$ & $31.29( \pm 2.00 \mathrm{bC}$ \\
\hline Elaidic $(18: 1 \omega-9 t)$ & $2.69( \pm 0.78) \mathrm{aA}$ & $3.12( \pm 0.80) \mathrm{bA}$ & $4.63( \pm 0.05) \mathrm{aB}$ & $3.83( \pm 0.43) \mathrm{bB}$ & $2.29( \pm 0.28) \mathrm{aC}$ & $2.12( \pm 0.12) \mathrm{aC}$ \\
\hline Non identified & $94.45( \pm 61.85)$ aA & $65.17( \pm 15.7) \mathrm{bA}$ & $114.3( \pm 16.5) \mathrm{aB}$ & $86.03( \pm 15.99) b B$ & $46.67( \pm 5.45) \mathrm{aC}$ & $44.84( \pm 3.37) b C$ \\
\hline$\Sigma$ Saturate & $176.57( \pm 8.92)$ aA & $151.7( \pm 1.85) \mathrm{bA}$ & $249.3( \pm 1.78) \mathrm{aB}$ & $228.38( \pm 2.08) b B$ & $117.45( \pm 2.1) \mathrm{aC}$ & $113.0( \pm 1.08) b C$ \\
\hline$\Sigma$ Unsaturate & $318.62( \pm 8.2)$ aA & $206.8( \pm 1.22) \mathrm{bA}$ & $474.5( \pm 0.77) \mathrm{aB}$ & $431.78( \pm 1.23) \mathrm{bB}$ & $200.33( \pm 1.8) \mathrm{aC}$ & $191.3( \pm 0.98) b C$ \\
\hline$\Sigma$ Poli-unsaturated & $200.8( \pm 8.90) \mathrm{aA}$ & $165.5( \pm 1.06) \mathrm{bA}$ & $303.6( \pm 1.12) \mathrm{aB}$ & $276.63( \pm 1.84) \mathrm{bB}$ & $126.38( \pm 1.9) \mathrm{Ac}$ & $121.6( \pm 1.08) \mathrm{aC}$ \\
\hline$\Sigma$ Mono-unsaturated & $117.8( \pm 7.50) \mathrm{aA}$ & $95.26( \pm 1.39) \mathrm{bA}$ & $170.9( \pm 0.42) \mathrm{aB}$ & $155.15( \pm 0.62) b B$ & $73.95( \pm 1.63) \mathrm{aC}$ & $69.97( \pm 0.89)$ bC \\
\hline PUFA/FAS6 & $1.13( \pm 8.91) \mathrm{aA}$ & $1.09( \pm 1.45) \mathrm{aA}$ & $1.21( \pm 1.45) \mathrm{aB}$ & $1.21( \pm 1.96) \mathrm{aB}$ & $1.07( \pm 2.05) \mathrm{aA}$ & $1.07( \pm 1.08) \mathrm{aA}$ \\
\hline$\Sigma \omega-3$ & $134.8( \pm 10.4) \mathrm{aA}$ & $106.8( \pm 1.12) \mathrm{bA}$ & $197.85( \pm 1.7) \mathrm{bB}$ & $181.37( \pm 2.13) \mathrm{bB}$ & $82.85( \pm 2.22) \mathrm{aC}$ & $80.45( \pm 1.27)$ bC \\
\hline$\Sigma \omega-6$ & $65.96( \pm 6.82) \mathrm{aA}$ & $58.75( \pm 0.99) \mathrm{bA}$ & $105.7( \pm 0.37) \mathrm{aB}$ & $95.26( \pm 1.45) \mathrm{bB}$ & $43.53( \pm 1.57) \mathrm{aC}$ & $41.19( \pm 0.84) \mathrm{bC}$ \\
\hline$\omega-6 / \omega-3$ & $1: 2.04( \pm 1.53) \mathrm{aA}$ & $1: 1.81( \pm 0.63) \mathrm{bA}$ & $1: 1.87( \pm 0.62) \mathrm{aB}$ & $1: 1.9( \pm 1.46) \mathrm{aB}$ & $1: 1.9( \pm 1.41) \mathrm{aB}$ & $1: 1.95( \pm 1.06) \mathrm{aB}$ \\
\hline EPA + DHA (mg/100g) & $119.14( \pm 19.0) \mathrm{aA}$ & $96.96( \pm 2.01) \mathrm{bA}$ & $181.4( \pm 3.10) \mathrm{aB}$ & $167.23( \pm 3.89) \mathrm{bB}$ & $74.51( \pm 4.01) \mathrm{aC}$ & $72.42( \pm 2.29) \mathrm{Bc}$ \\
\hline
\end{tabular}

${ }^{*}$ Averages and standard deviation of two samples evaluated in triplicate. Different capitals in the same row and different lowercase letters, in the same column, indicate a significant difference at $5 \%$ probability, by Tukey's test.

There was a significant difference $(\mathrm{p}<0.05)$ between the fatty acids content of the in natura samples compared to the samples with addition of white onion at time zero and during storage, and lower values were detected in shrimp with addition of white onion. It was evidenced that the use of this vegetable as an antioxidant measure did not act expressively preventing this phenomenon. One possible explanation is the quercetin - flavonoid compound of greatest expressiveness in vegetables of the genus Allium (Souza et al., 2010) and considered to have a great antioxidant potential (Decker, 1997). However, it is worth mentioning that some antioxidants can initiate an auto-oxidation process and behave like pro-oxidants under certain conditions (Bouayed \& Bohn, 2010). Also, the pro-oxidant or antioxidant activity may depend on the concentration of the bioactive compound (Dai \& Mumper, 2010). Tagliazucchi et al. (2005), affirm that the increase of the enzymatic activity of pepsin depends on the polyphenol concentration. The order of this effect of different polyphenols in the initial increase of the reaction rate (digestive pepsin activity) and it was observed that quercetin is in a higher efficiency position than epigallocatechin-3-gallate and catechin, in increasing the initial reaction rate, which may lead to faster digestion of compounds.

In the freezing process, the cell barrier breaks down, leading to extravasation of aqueous compounds, which may have contributed to the reduction of the antioxidant capacity of quacertin, since the presence of water generally decreases the activity of antioxidants, because hydrogen-bound complexes are less effective in eliminating lipid radicals by hydrogen donation (Paiva-Martins \& Gordon, 2005).

The polyunsaturated/saturated (PUFA/FAS) ratios for the in natura and with onion addition samples at 0,45 and 90 days of storage can be considered as not harmful to health, since when it is lower than 0.45 it is an unhealthy diet, due to its potential for induction of increased blood cholesterol, leading mainly to the increase of cardiovascular diseases (Department Of Health And Social Security apud Furuya, 2008).

As for the n-6/n-3 ratio, the Department of Health (1994), recommends a maximum of $4: 1$, while the Scientific Review Committee (1990) recommends a range interval of 5:1 to 10:1. However, ratios lower than 1:1 are not recommended because 
they inhibit the transformation of linoleic acid into arachidonic acid (Novello et al., 2008). The results found for the in natura and with white onion samples are in accordance with the literature, at all time intervals.

\section{Total Carotenoids}

The results of the total concentration of the carotenoid pigments obtained by the ethanol extraction of the samples in natura and with the addition of white onion (time zero and stored under different freezing times) are presented in Table 3.

The total carotenoid content of fresh and onion white shrimp samples at zero time did not show a significant difference $(\mathrm{p}>0.05)$ and were similar to those detected by Lira et al. (2017), in raw "Vila Franca" shrimp fillets $\left(0.57 \mu \mathrm{g} \cdot \mathrm{mL}^{-1}\right)$.

The freezing storage resulted in a significant reduction $(\mathrm{p}<0.05)$ in the total carotenoid content of fresh and onion white shrimp after 45 days, which corresponded to $30 \%$ and $43 \%$, respectively. This reduction can be associated to the fact that in the storage period, due to the instability of its structure, the carotenoids can undergo isomerization and oxidation, due to the decrease of humidity, generating loss of dye capacity and consequently loss / reduction of antioxidant activity (Rodriguez-Amaya \& Kimura, 2005; Rios, 2009; Barbosa et al., 2012). Lira et al. (2017) detected a superiority of the antioxidant potential of carotenoids when compared to ascorbic acid, especially in cooked steaks and bark. However, due to its double bonded structure, carotenoids are sensitive to light, temperature, acidity and oxidation reactions (Ambrosio et al., 2006). So that, the same polyenic chain responsible for the desirable properties is the cause of the instability of carotenoids (Rodriguez-Amaya \& Kimura, 2005) under heat treatment during domestic preparation, industrial processing and food storage (Meléndez-Martínez et al., 2004), with a lack of their nutritional and beneficial properties.

Lira et al. (2017) detected a significant difference ( $\mathrm{p}>0.05)$, of $39 \%$, in carotenoid concentrations, in samples of "Vila franca" shrimp in natura, after 90 days under freezing conditions. In the present study, after 90 days of freezing, a significant loss $(\mathrm{p}<0.05)$ of $28 \%$ was detected in the samples with addition of white onion, in relation to 45 days.

The results obtained in the present study show that white onion did not exert antioxidant activity on carotenoids, as it did in relation to fatty acids.

Table 3. Total carotenoid content ( $\mu$ g. $\left.\mathrm{mL}^{-1}\right)$ of "Vila Franca" shrimp in natura and with addition of white onion stored under freezing.

\begin{tabular}{ccccc}
\hline \multirow{2}{*}{$\begin{array}{c}\text { "Vila Franca" } \\
\text { shrimp }\end{array}$} & & \multicolumn{3}{c}{ Total Carotenoids $\left(\mu \mathrm{g} \cdot \mathrm{mL}^{-1}\right)$} \\
\cline { 1 - 5 } \cline { 3 - 5 } Group & 0 & \multicolumn{3}{c}{ Time under freezing (days) } \\
\cline { 2 - 5 } In natura & $0.50( \pm 0.003) \mathrm{Aa}$ & $0.33( \pm 0.006) \mathrm{Ba}$ & $0.35( \pm 0.020) \mathrm{Ba}$ \\
With onion & $0.58( \pm 0.002) \mathrm{Aa}$ & $0.36( \pm 0.007) \mathrm{Ba}$ & $0.25( \pm 0.002) \mathrm{Ca}$ \\
\hline
\end{tabular}

*Averages and standard deviation of two samples evaluated in triplicate. Different capitals in the same row and different lowercase letters, in the same column, indicate a significant difference at $5 \%$ probability, by Tukey's test.

\section{Total phenols}

The genus Allium has more than 500 members, with different appearance, color and flavor, but they have similarities in biochemistry, phytochemistry and nutraceutical content. They have antioxidant activity, free radical interceptors, inhibitors of lipid peroxidation (Escarpa \& González, 2001) and are derived from secondary metabolism, which is characterized by the presence of sulfur and numerous phenolic compounds (Griffiths et al., 2002). synthesis can be increased in response to a stress condition (Jacques \& Zambiazi, 2011). The main phenolic component of the different species of onion (A. cepa L.) is quercetin, (Souza et al., 2010). According to Haida et al. (2014), phenolic compounds can be influenced by external factors, including storage temperature.

The total phenolic content of white onion observed in the present study is shown in Table 4.

The values of phenolic compounds detected at time zero were lower than those found by Recart et al. (2009), ranging from $224.43 \mu \mathrm{g} / \mathrm{g}$ to $230.64 \mu \mathrm{g} / \mathrm{g}$ in different classes of commercial onions. The results obtained by Souza et al. (2010), on aqueous onion extract $(283.3 \mu \mathrm{g} / \mathrm{g})$ and Nuutila et al. (2003), on red onion $(270.5 \mu \mathrm{g} / \mathrm{g})$ were also compared. Lower values were found by Nuutila et al. (2003) for giant onion $(84.5 \mu \mathrm{g} / \mathrm{g})$ and yellow onion $(155 \mu \mathrm{g} / \mathrm{g})$. Siddiq et al. (2013) found a reduction in the phenolic compounds content from time 0 to day 14 , followed by increase at the end of storage in minimally processed yellow onion and stored at $4^{\circ} \mathrm{C}$ for 21 days.

After 90 days of storage, the concentration of total phenols increased significantly ( $p>0.05$ ) by $11.7 \%$, in relation to time zero. Siddiq et al. (2013) found an increase in the phenolic content during the storage of minimally processed onions and report that it was due to the physiological response of the onion, due to the stress caused by the treatment and the storage time employed. According to Chang et al. (2005), food processing can accelerate the release of the phenolic compounds from the matrix, from the breakdown of the cellular constituents.

In spite of the linear increase in phenol content during storage, no positive correlation was observed between the phenol concentrations and the antioxidant activity exerted by the white onion, in relation to the profile of fatty acids and carotenoids. Melo et al. (2006) also found no positive relationship between the phenol content and the antioxidant capacity of several fruits and vegetables, including white onion, evidencing that the antioxidant capacity of an extract can not be explained solely on the basis of its content phenols, it is also necessary to characterize the structure of the active compound (Heinonen et al., 1998).

Table 4. Total phenolics content (mg/g) on white onion stored under different time intervals of freezing.

\begin{tabular}{ccc}
\hline \multicolumn{3}{c}{ Total Phenolics } \\
\hline \multicolumn{3}{c}{ Time under freezing (days) } \\
\hline 0 & 45 & 90 \\
\hline $216.7 \mathrm{a}$ & $220.6 \mathrm{a}$ & $242.1 \mathrm{~b}$ \\
\hline
\end{tabular}

The averages followed by lowercase letters on the same line differ statistically from one another. The Tukey's test was applied at a 5\% probability level. 


\section{Conclusions}

The in natura "Vila Franca" shrimp is as a source of proteins of high biological value, carotenoids, as well as n-3 polyunsaturated fatty acids (EPA and DHA), n-6 (arachidonic and linoleic), acids n-9 monounsaturated fatty acids (oleic and palmitoleic) and saturated fatty acids (palmitic and stearic). The addition of white onion caused a significant reduction $(p<0.05)$ in fatty acid concentrations. Storage under freezing did not affect ash and protein content of in natura samples and shrimp samples with white onion. However, significant reduction $(\mathrm{p}<0.05)$ was observed in the total carotenoids content, in the in natura samples and samples with the addition of white onion, after 45 days and at 90 days of freezing. Significant loss $(\mathrm{p}<0.05)$ was detected only in the samples with addition of white onion, in relation to 45 days.

In the two groups analyzed, there was a significant $(\mathrm{p}<0.05)$ increase in saturated, monounsaturated and polyunsaturated fatty acids contents after 45 days of storage. At 90 days, there was a significant decline $(\mathrm{p}<0.05)$, probably due to the development of oxidative reactions.

The concentration of total phenols in white onion after 90 days of storage under freezing was significantly higher $(\mathrm{p}<0.05)$ than that detected at time 0 . However, a negative impact of the antioxidant activity of white onion was observed. profile of fatty acids and carotenoid content.

\section{References}

Abreu, D. A. P., Losada, P. P., Maroto, J., \& Cruz, J. M. (2011). Natural antioxidant active packaging film and its effect on lipid damage in frozen blue shark (Prionace glauca). Innovative Food Science \& Emerging Technologies, 12(1), 50-55. http://dx.doi.org/10.1016/j. ifset.2010.12.006.

Ackman, R. G. (1989). Nutritional composition of fats in seafood. Progress in Food \& Nutrition Science, 13(3-4), 161-289. PMid:2699043.

Ambrosio, C. L. B., Campos, F. A. C., \& Faro, Z. P. (2006). Carotenoids as an alternative against hypovitaminosis A. Revista de Nutrição, $19(2), 233-243$.

Araújo, H. M. P. (2006). Distribuição das espécies Paracalanidae (Copepoda. Crustacea) na plataforma continental de Sergipe e Alagoas. Brazilian Journal of Oceanography, 54(4), 173-181. http:// dx.doi.org/10.1590/S1679-87592006000300001.

Armenta, R. E., \& Guerrero-Legarreta, I. (2009). Stability studies on astaxanthin extracted from fermented shrimp byoproducts. Journal of Agricultural and Food Chemistry, 57(14), 6095-6100. http://dx.doi. org/10.1021/jf901083d. PMid:19548684.

Association of Official Analytical Chemists. (2000). Official Methods of Analysis (vol. 2, 15th ed.). Gaithersburg: AOAC Internacional.

Barbosa, N. A., Paes, M. C. D., Pereira, I. A. Fo., Guimarães, P. E. O., \& Pereira, J. (2012). Retenção de carotenoides durante o armazenamento de espigas de milho verde biofortificado com precursores da vitamina A. In Empresa Brasileira de Pesquisa Agropecuária - Embrapa (Ed.), XXIX Congresso Nacional De Milho e Sorgo (pp. 3778- 3784). Águas de Lindóia: Artigo em Anais de Congresso - ALICE.

Becerra, J. A. H., Flores, A. A. O., \& Alfaro, G. V. (2014). Cholesterol oxidation and astaxanthin degradation in shrimp during sun drying and storage. Food Chemistry, 145, 832-839. http://dx.doi.org/10.1016/j. foodchem.2013.08.098. PMid:24128553.
Bouayed, J., \& Bohn, T. (2010). Exogenous antioxidants-double-edged swords in cellular redox state: health beneficial effects at physiologic doses versus deleterious effects at high doses. Oxidative Medicine and Cellular Longevity, 3(4), 228-237. http://dx.doi.org/10.4161/ oxim.3.4.12858. PMid:20972369.

Bourvellec, C., \& Renard, C. M. G. C. (2012). Interactions between polyphenols and macromolecules: quantification methods and mechanisms. Critical Reviews in Food Science and Nutrition, 52(3), 213-248. http://dx.doi.org/10.1080/10408398.2010.499808 . PMid:22214442.

Chang, H. S., Yamato, O., Yamasaki, M., Ko, M., \& Maede, Y. (2005). Growth inhibitory effect of alk(en)yl thiosulfates derived from onion and garlic in human immortalized and tumor cell lines. Cancer Letters, 223(1), 47-55. http://dx.doi.org/10.1016/j.canlet.2004.10.008. PMid:15890236.

Costa, V. P., Arcieri, E. S., \& Harris, A. (2009). Blood pressure and glaucoma. The British Journal of Ophthalmology, 93(10), 1276-1282. http://dx.doi.org/10.1136/bjo.2008.149047. PMid:19336425.

Dai, J., \& Mumper, R. J. (2010). Fenólicos de plantas: extração, análise e suas propriedades antioxidantes e anticancerígenas. Molecules (Basel, Switzerland), 15(10), 7313-7352. http://dx.doi.org/10.3390/ molecules15107313. PMid:20966876.

Decker, E. A. (1997). Phenolics: prooxidants or antioxidants? Nutrition Reviews, 55(11), 396-398. PMid:9420450.

Department of Health. (1994). Report on health and social subjects - Nutritional aspects of cardiovascular disease. HMSO, 46, 37-46.

Elfalleh, W., Hannachi, H., Tlili, N., Yahia, Y., Nasri, N., \& Ferchichi, A. (2012). Total phenolic contents and antioxidant activities of pomegranate peel, seed, leaf and flower. Journal of Medicinal Plants Research, 6(32), 4724-4730. http://dx.doi.org/10.5897/JMPR11.995.

Escarpa, A., \& González, M. C. (2001). Approach to the content of total extractable phenolic compounds from different food samples by comparison of chromatographic and spectrophotometric methods. Analytica Chimica Acta, 427(1), 119-127. http://dx.doi.org/10.1016/ S0003-2670(00)01188-0.

Folch, J., Lees, M., \& Stanley, G. H. S. (1957). A simple method for the isolation and purification of total lipide from animal tissues. The Journal of Biological Chemistry, 226(1), 497-509. PMid:13428781.

Furuya, W. M. (2008). Perfil de ácidos graxos de pós-larvas de camarão da malásia (macrobrachium rosenbergii) alimentados com dietas com semente de linhaca e sub-produto de tomate. Boletim do Instituto de Pesca, 34(4), 473-481.

Furuya, W. M., Santos, V. G., Silva, L. C. R., Furuya, V. R. B., \& Sakaguti, E. S. (2006). Exigências de lisina digestível para juvenis de tilápia-doNilo. Revista Brasileira de Zootecnia, 35(3), 937-942. http://dx.doi. org/10.1590/S1516-35982006000400001.

Griffiths, G., Trueman, L., Crowther, T., Thomas, B., \& Smith, B. (2002). Onions: a global benefits to health. Phytotherapy Research, 16(7), 603-615. http://dx.doi.org/10.1002/ptr.1222. PMid:12410539.

Haida, K. S., Silva, F. J., Coelho, S. R. M., Lima, D. S., Abrão, R. M., \& Haida, K. Y. (2014). Caracterização físico-química e atividade antioxidante de amoreira-preta (Morus nigra L.). Revista Brasileira de Ciências da Saúde, 12(40), 21-28.

Hartman, L., \& Lago, R. C. A. (1973). Rapid preparation of fatty acid methyl esters from lipids. Laboratory Practice, 22(6), 475-476. PMid:4727126.

Hathwar, S. C., Rai, A. K., Modi, V. K., \& Narayan, B. (2012). Characteristics and consumer acceptance of healthier meat and meat product formulations-a review. Journal of Food Science and 
Technology, 49(6), 653-664. http://dx.doi.org/10.1007/s13197-0110476-z. PMid:24293684.

Haugaard, P., Hansen, F., Jensen, M., \& Grunert, K. G. (2014). Consumer atitudes toward new technique for preserving organic meat using herbs and berries. Meat Science, 96(1), 126-135. http://dx.doi. org/10.1016/j.meatsci.2013.06.010. PMid:23896146.

Heinonen, I. M., Lehtonen, P. J., \& Hopia, A. (1998). Antioxidative activity of berry and fruit wines and liquor. Journal of Agricultural and Food Chemistry, 46(1), 25-31. http://dx.doi.org/10.1021/ jf970489o. PMid:10554191.

Jacques, A. C., \& Zambiazi, R. C. (2011). Fitoquímicos em amorapreta (Rubus spp.). Ciências Agrárias, 32(1), 245-260. http://dx.doi. org/10.5433/1679-0359.2011v32n1p245.

Kulawik, P., Ozogul, F., Glew, R., \& Ozogul, Y. (2013). Significance of antioxidants for seafood safety and human health. Journal of Agricultural and Food Chemistry, 61(3), 475-491. http://dx.doi. org/10.1021/jf304266s. PMid:23256644.

Leygonie, C., Britz, T. J., \& Hoffman, L. C. (2012). Impact of freezing and thawing on the quality of meat: review. Meat Science, 91(2), 93-98. http://dx.doi.org/10.1016/j.meatsci.2012.01.013. PMid:22326063.

Lira, G. M., Barros Silva, K. W., Figueirêdo, B. C., \& Bragagnolo, N. (2014). Impact of smoking on the lipid fraction and nutritional value of seabob shrimp (Xiphopenaeus kroyeri, Heller, 1862). Lebensmittel-Wissenschaft + Technologie, 58(1), 183-187. http:// dx.doi.org/10.1016/j.lwt.2014.02.057.

Lira, G. M., Lopez, A. M. Q., Firmino, G. O., Santos, S. D., \& Bezerra, R. S. (2017). Total carotenoids and antioxidant activity of fillets and shells (in natura or cooked) of "Vila Franca" shrimp (Litopenaeus Schmitti) in different intervals of storage under freezing. Ciência e Agrotecnologia, 41(1), 94-103. http://dx.doi.org/10.1590/141370542017411023616.

Livesey, G. (1990). Valores energéticos de carboidratos e dietas não disponíveis: uma investigação e análise. The American Journal of Clinical Nutrition, 51(4), 617-637. http://dx.doi.org/10.1093/ ajcn/51.4.617. PMid:2138862.

Meda, A., Lamien, C. E., Romito, M., Millogo, J., \& Nacoulma, O. G. (2005). Determination of the total phenolic. flavonoid and proline contents in Burkina Fasan honey. as well as their radical scavenging activity. Food Chemistry, 91(1), 571-577. http://dx.doi.org/10.1016/j. foodchem.2004.10.006.

Meléndez-Martínez, A. J., Vicario, I. M., \& Heredia, F. J. (2004). Importância nutricional de los pigmentos carotenoides. Archivos Latinoamericanos de Nutricion, 54(2), 149-154. PMid:15586682.

Melo, E. A., Maciel, M. I. S., Lima, V. L. A. G., Leal, F. L. L., Caetano, A. C. S., \& Nascimento, R. J. (2006). Capacidade antioxidante de hortaliças usualmente consumidas. Food Science and Technology (Campinas), 26(3), 639-644. http://dx.doi.org/10.1590/S010120612006000300024.

Novello, D., Franceschini, P., \& Quintiliano, D. A. (2008). A importância dos ácidos graxos $\omega$-3 e $\omega$-6 para a prevenção de doenças e na saúde humana. Revista Salusvita, 2(1), 77-87.

Nuutila, A. M., Puupponen-Pimiä, R., Aarni, M., \& Oksman-Caldentey, K. M. (2003). Comparison of antioxidant activities of onion and garlic extracts by inhibition of lipid peroxidation and radical scavenging activity. Food Chemistry, 81(4), 485-493. http://dx.doi.org/10.1016/ S0308-8146(02)00476-4.

Paiva-Martins, F., \& Gordon, H. M. (2005). Interactions of ferric ions with olive oil phenolic compounds. Journal of Agricultural and Food Chemistry, 53(7), 2704-2709. http://dx.doi.org/10.1021/jf0481094. PMid:15796614.
Pedrosa, L. F. C., \& Cozzolino, S. M. (2001). Composição centesimal e de minerais de mariscos crus e cozidos da cidade de Natal/ RN. Food Science and Technology (Campinas), 21(2), 154-157. http:// dx.doi.org/10.1590/S0101-20612001000200006.

Pereira, A. (2003). Guia prático de utilização do SPSS - análise de dados para as ciências sociais e psicologia (4. ed.) Lisboa: Edições Sílabo.

Perini, J., Stevanato, F. B., Sargi, S. C., Visentainer, J. E. L., Dalalio, M. M. D. O., Matshushita, M., Souza, N. E. D., \& Visentainer, J. V. (2010). Ácidos graxos poli-insaturados n-3 e n-6: metabolismo em mamíferos e resposta imune. Revista de Nutrição, 23(6), 1075-1086. http://dx.doi.org/10.1590/S1415-52732010000600013.

Pokorny, J., Yanishlieva, N., \& Gordon, M. (2008). Antioxidants in food. Practical Applications CRC Press, 2(1), 259-286.

Recart, V. M., Rocha, M., Cipolatti, E. P., \& Badiale-Furlong, E. (2009). Estudo das condições de extração de compostos fenólicos de cebola (Allium cepa L.). Revista do Instituto Adolfo Lutz, 68(2), 192-200.

Rios, A. O. (2009). Proteção de carotenoides contra radicais livres gerados no tratamento de câncer com cisplatina. Revista Alimento e Nutrição, 20(1), 342-350.

Rodriguez-Amaya, D. B., \& Kimura, M. (2005). Sreening method for dry corn. In D. B. Rodriguez-Amaya \& M. Kimura (Eds.), HarvestPlus handbook for carotenoid analysis (HarvestPlus Technical Monograph Series, No. 2, pp. 37-42). Washington/Cali: International Food Policy Research Institute - IFPRI/International Center for Tropical Agriculture - CIAT.

Ruxton, C. H. S., Calder, P. C., Reed, S. C., \& Simpson, M. J. A. (2005). The impact of long chain $\mathrm{n}-3$ polyunsaturated fatty acids on human health. Nutrition Research Reviews, 18(1), 113-129. http://dx.doi. org/10.1079/NRR200497. PMid:19079899.

Santos, S. D., Cahú, T. B., Firmino, G. O., Castro, C. C., Carvalho, L. B. Jr, Bezerra, R. S., \& Lima, J. Fo. (2012). Shrimp waste extract and astaxanthin: Rat alveolar macrophage, oxidative stress and inflammation. Journal of Food Science, 77(7), 141-146. http://dx.doi. org/10.1111/j.1750-3841.2012.02762.x. PMid:22757706.

Schiedt, K., \& Liaaen-Jensen, S. (1995). Isolation and analysis. In G. Britton, H. Pfander \& S. Liaaen-Jensen (Eds.), Isolation and analysis (Vol. 1, No. 1, pp. 81-108). Basel: Birkhauser Verlag.

Scientific Review Committee. (1990). Nutrition recommendations. Ottawa: Canadian Government Publishing Centre, Supply and Services Canada.

Selani, M. M., Contreras-Castillo, C. J., Shirahigue, L. D., Gallo, C. R., Plata-Oviedo, M., \& Montes-Villanueva, N. D. (2011). Wine industry residues extracts as natural antioxidants in raw and cooked chicken meat during frozen storage. Meat Science, 88(3), 397-403. http://dx.doi.org/10.1016/j.meatsci.2011.01.017. PMid:21342750.

Siddaiah, D., Reddy, G. V. S., Raju, C. V., \& Chandrasekhar, T. C. (2001). Changes in lipids, protein and kamaboko forming ability of silver carp (Hypophthalmichthys molitrix) minced during frozen storage. Food Research International, 34(1), 47-53. http://dx.doi.org/10.1016/ S0963-9969(00)00127-7.

Siddiq, M., Roidoung, S., Sogi, D. S., \& Dolan, K. D. (2013). Total phenolics, antioxidant properties and quality of fresh-cut onions (Allium cepa L.) treated with mild-heat. Food Chemistry, 136(2), 803-806. http:// dx.doi.org/10.1016/j.foodchem.2012.09.023. PMid:23122130.

Simon, S. J. G. B., Sancho, R. A. S., Lima, F. A., Cabral, C. C. V. Q., Souza, T. M., Bragagnolo, N., \& Lira, G. M. (2012). Interaction between soybean oil and the lipid fraction of fried Pitu prawn. Lebensmittel-Wissenschaft and Technologie. Food Science and Technology (Campinas), 48(1), 120-126. 
Souza, M. M., Oliveira, M. S., Rocha, M., \& Furlong, E. B. (2010). Avaliação da atividade antifúngica de extratos fenólicos de cebola, farelo de arroz e microalga Chlorella phyrenoidosa. Food Science and Technology (Campinas), 30(3), 680-685. http://dx.doi.org/10.1590/ S0101-20612010000300018.

Tagliazucchi, D., Verzelloni, E., \& Conte, A. (2005). Effect of some phenolic compounds and beverages on pepsin activity during simulated gastric digestion. Journal of Agricultural and Food Chemistry, 53(22), 8706-8713. http://dx.doi.org/10.1021/jf058074n. PMid:16248575.

Xia, X., Kong, B., Liu, Q., \& Liu, J. (2009). Physicochemical change and protein oxidation in porcine Longissimus dorsi as influenced by different freeze-thaw cycles. Meat Science, 83(2), 239-245. http:// dx.doi.org/10.1016/j.meatsci.2009.05.003. PMid:20416749. 